\title{
Insulin-like Growth Factor I and Urokinase-type Plasminogen Activator Bioregulation System as a Survival Mechanism of Prostate Cancer Cells in Osteoblastic Metastases: Development of Anti-Survival Factor Therapy for Hormone-Refractory Prostate Cancer
}

\author{
Michael Koutsilieris, Constantine Mitsiades and Antigone Sourla \\ Department of Experimental Physiology, Medical School, University of Athens, \\ Greece
}

\section{Introduction}

Androgen ablation therapy is the first-line therapy in metastatic prostate cancer. It initially offers an objective clinical response, but eventually is stalled by the ominous development of refractoriness to hormonal therapy (stage D3). This ominous event signifies poor prognosis, uncontrolled tumor growth and curtailed survival to a median of only 10 months (1). Salvage chemotherapy does not improve the overall survival of stage D3 patients $(2,3)$.

The bone is the most prevalent site for metastases of prostate cancer (4). These lesions are associated with a potent local osteoblastic reaction, in contrast to the overwhelming majority of other solid tumors, whose bony metastases are generally associated with osteolysis $(5,6)$. Osteoblastic metastases almost always represent the first and, frequently, the exclusive site of disease progression to stage D3 $(3,7-9)$. The number of skeletal metastatic foci is the most powerful independent prognostic factor associated with limited response to hormone ablation therapy and poor survival of advanced prostate cancer (7-9). Disease progression to hormone-refractoriness frequently occurs only in the osteoblastic metastases, even though hormonal therapy may still provide ad-

Address correspondence and reprint requests to: Michael Koutsilieris, M.D. Ph.D, Department of Experimental Physiology, Medical School, University of Athens, 75 Micras Asias, Goudi 11527, Athens, Greece. Phone: (30)-107711222; Fax: (30)-1-7774902; e-mail:

mkouts@medscape.com equate and sustained control of disease at the primary site (7-12). Consequently, the bone may not be just a passive, innocent bystander that suffers the consequences of metastatic tumor growth, but it may constitute the favorable microenvironment for the homing of metastatic prostate cancer cells (13-15). This may be secondary to interactions of prostate cancer cells with osteoblasts, to promote both the growth of metastatic prostate cancer cells and the osteoblastic reaction (13-17).

Recently, bone-derived growth factors were reported to protect metastatic prostate cancer cells from chemotherapy-induced apoptosis, introducing the novel concept of bone-derived survival factors (18-20). We reviewed the current knowledge on osteoblast-derived survival factors, their relationship with local factors, such as the insulin-like growth factor I (IGF-I) and urokinase-type plasminogen activator (UPA) bioregulation system. These factors are implicated in the osteoblastic reaction and the benchto-bedside development of an anti-survival factor therapy, which has provided encouraging preliminary data in a phase II clinical trial with terminally ill, hormone-refractory and chemotherapy-resistant prostate cancer patients.

\section{Role of the UPA/Plasmin/IGF-I Bioregulation System in Osteoblastic Metastasis}

The cellular constituents of the bone microenvironment (osteoblasts, osteocytes, stromal 
cells, immune system cells or hematopoietic cells) are significant sources of growth factors, most of which serve as powerful modulators of the process of bone remodeling $(13,15)$. Prostate cancer cells express receptors for many of these growth factors and respond to them in proliferation assays in vitro $(14,16,17,21,22)$. Interestingly, prostate cancer cells themselves secrete a constellation of growth factors, which overlaps extensively with the bone cellderived factors. These factors include transforming growth factor beta 1 (TGF- $\beta 1$ ) (23), fibroblast growth factors (FGFs) (24-26) bone morphogenetic proteins (BMPs) $(27,28)$ and endothelin-1 (29,30). These prostate-derived mitogens may not only stimulate cancer cells themselves in an autocrine manner, but can locally modulate the bone remodeling process at sites of skeletal metastases by stimulating the proliferation and/or function of osteoblasts $(14,16,17,21,22,30-32)$. The role of these peptides in promoting the osteoblastic reaction may be synergistic or additive; whereas, other factors that share similar or chemotactic properties may still be unidentified $(13,15,23)$. Therefore, metastatic prostate cancer cells and bone cells, such as osteoblasts, are mutually interacting via growth factors that may target both cell types.

Since the local osteoblastic reaction involves predominantly osteoblasts $(5,6)$, it was hypothesized early on that a prostate cancer cell-derived mitogen may specifically act on osteoblasts (14). Indeed, an osteoblast-specific mitogen, without substantial effect on fibroblasts, was detected in extracts from prostate cancer, benign prostatic hyperplasia and normal prostate tissues, as well as conditioned media (CM) of human PC-3 and rat PA-III prostate cancer cells $(16,17,31,33)$. Purification of this osteoblast-specific mitogen revealed $100 \%$ homology with the N-terminal uPA (33). uPA is synthesized as a single-chain precursor, termed pro-uPA, which is converted to a high molecular weight uPA (HMW-uPA) comprised of two chains ( $\alpha$ - and $\beta$-chain, corresponding to the $\mathrm{N}$ - and C-terminals of pro-uPA, respectively) linked by a disulfide bridge, with the $\beta$ chain possessing serine protease activity (34). uPA acts via its receptor (uPA-R), which lacks intracellular or transmembrane domains and, instead, is, anchored to the cell membrane by a monomeric glycerolphosphoinoside (GPI) moiety. Pro-uPA can be converted to active uPA, by human kallikrein 2 (hK2) or plasmin, but not by prostate-specific antigen (PSA) (35). Purified rat and human uPA selectively stimulated the proliferation of rat UMR 106 and human MG-63/SaOS-2 osteoblast-like cells (36).

The identification of a prostate-derived peptide with osteoblast-specific mitogenic properties provided important insights into the pathophysiology of metastatic prostate cancer, but at the same time, prompted further unanswered questions. First, it documented that the osteoblastic reaction was a specific response of the osteoblasts to the presence of metastatic prostate cancer cells, produced by a highly specific intercellular interaction involving the uPA/plasmin cascade (36). Moreover, the protease activity of uPA could play a dual role in both the extracellular matrix degradation processes that accompany the establishment of metastasis and the blastic reaction of osteoblasts. Through its $\beta$-chain protease activity, uPA converted plasminogen to plasmin, a serine protease capable of activating a cascade of extracellular proteases, which, in their turn, degraded extracellular matrix proteins (37). uPA alone could directly cleave fibronectin, while plasmin, formed by cleavage of plasminogen by UPA, activated pro-collagenases into collagenases, orchestrating a massive proteolytic degradation of the extracellular matrix (38). Therefore, UPA-R facilitated UPA activation at focal sites adjacent to the cell surface, which were also the preferred sites for uPAmediated protein degradation $(37,38)$. Competitive displacement of UPA from UPA-R at the GPI-mediated cellular binding sites, resulted in a decreased matrix degradation in vitro (39). The uPA expression and uPA-mediated extracellular matrix degradation by prostate cancer cells correlated with their metastatic behavior in vivo (40). In animal models, uPA overexpression correlated with higher, both skeletal and nonskeletal, tumor burden (41); whereas, uPA down-regulation reduced metastatic tumor size $(42,43)$. Elevated uPA levels in prostate cancer patients' blood correlated with far advanced metastatic disease, as well as with increased number of bone metastases (43).

However, it was not entirely clear how a protease could function as a growth factor. The complex molecular physiology of uPA encouraged diverse attempts to explain this osteoblast-stimulating role. One hypothesis holds that cleavage of a-chain uPA by, yet unidentified, proteinases produced by the prostate cancer cell specifically generates the 
amino-terminal fragment (ATF, or ATF-uPA) and the low-molecular weight uPA (LMWuPA), a short residual $\alpha$-chain linked to an intact $\beta$-chain, which retains proteolytic activity. Close to the N-terminus of the ATF-uPA, lies the "growth factor domain" (GFD), a sequence structurally similar to the epidermal growth factor (EGF) $(38,44)$. ATF-uPA was proposed to act per se as a prostate-derived mitogen for osteoblasts $(44,45)$. uPA- $R$ is expressed on both prostate cancer cells and osteoblasts, and the proposed model for such a potential direct mitogenic effect holds that, aside from intact UPA, ATF-uPA also binds to UPA-R on the osteoblast surface, transducing mitogenic signals (45). Indeed, ATF-uPA does up-regulate in human SaOS-2 osteoblast-like cells the expression of $c-m y c, c-j u n$ and $c-f o s$ genes in a timedependent manner (46). Tyrosine kinase inhibitors, such as herbimycin, block this effect, implicating tyrosine kinase signal transduction pathways in the stimulation of osteoblast proliferation by ATF-uPA. However, it remains undetermined how such a growth signal can be transduced by a GPI-anchored receptor that lacks an identifiable intracellular tyrosine kinase domain. Apparently, this hypothesis implies the presence of another, yet unidentified, novel molecule (receptor) which perhaps specifically binds $\mathrm{N}$-terminal uPA on osteoblasts (44-46).

An alternative hypothesis suggests that uPA converts plasminogen to plasmin, which hydrolyzes IGF-binding proteins (IGFBPs) (47). As a result of the IGFBPs of hydrolysis, the IGFs bound to these proteins are released. It is the release of bioactive IGFs that appears to mediate the growth-promoting role of uPA $(33,47,48)$. Therefore, the mitogenic activity of uPA may involve the IGF receptors and their intrinsic intracellular tyrosine kinase domains $(36,48)$. This notion comes from data documenting that pretreatment of the prostate cancer cells' CM with benzamidine and aprotinin, which block the protease activity of UPA, also abrogate the mitogenic activity of the $\mathrm{CM}$ on osteoblast-like cells $(33,44)$, while anti-IGF-I neutralizing antibodies block the mitogenic effect of human and rat UPA on human and rat osteoblasts, respectively (47). These data strongly suggest that a significant proportion of the mitogenic action of uPA on osteoblasts is, in fact, IGF-mediated $(45,49)$. It is important to note that uPA can also activate latent TGF- $\beta$, produced by prostate cancer cells and os- teoblasts, which also has important regulatory functions on osteoblasts and prostate cancer cells $(36,48,49)$. Moreover, IGFBP-3, a major target of uPA-mediated proteolysis, also can induce apoptosis of prostate cancer cells, via an IGF-independent mechanism (50). It is conceivable that UPA-mediated hydrolysis of IGFBP-3, aside from increasing the bioavailability of IGF-1, removes the pro-apoptotic stimulus of IGFBP- 3 on prostate cancer cells, thereby optimizing the survival of metastatic prostate cancer cells locally (Fig. 1). Therefore, the UPA/IGF bioregulation system is heavily implicated in the intercellular interactions between prostate cancer cells and osteoblasts (51). In addition to the UPA/IGFs system, other potentially co-existing bioregulation systems may be capable of promoting the homing of prostate adenocarcinoma cells to the bone and, possibly, may play an active role in the pathophysiology of the osteoblastic reaction $(3,13-15)$.

\section{Role of IGF-I and UPA Bioregulation System In the Development of Hormone- refractory and Chemotherapy- resistant Tumor Growth}

The elucidation of the uPA/plasmin/growth factors, such as IGFs, cascade opened new avenues of investigation concerning the microenviromental interactions of prostate cancer cells with the bone milieu. One of the important regulatory roles of this pathway is to modulate the local bioavailability of IGFs, promoting the local proliferation of prostate cancer cells $(36,48)$. However, the net changes in the total number of prostate cancer cells is decided by the balance between cell division and cell death. The rationale for hormone ablation therapy in metastatic prostate cancer is that androgens, via the function of the androgen receptor (AR), prevent the apoptotic cell death, rather than solely promote prostate cell growth. Double stranded oligonucleotide, containing the same DNA sequence as the androgen responsive element (ARE) at the regulatory regions of genes transcriptionally regulated by the AR, function as "decoy ARE" when transfected to prostate cancer cells and induce their apoptosis (52). Obviously, the androgen ablation therapy inactivates the AR function and facili- 


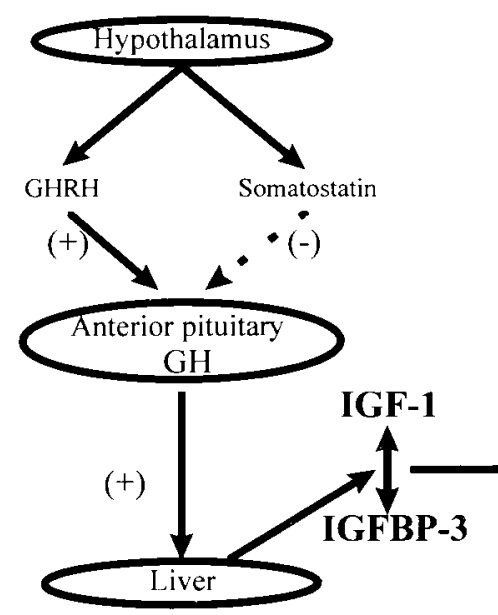

Endocrine loop

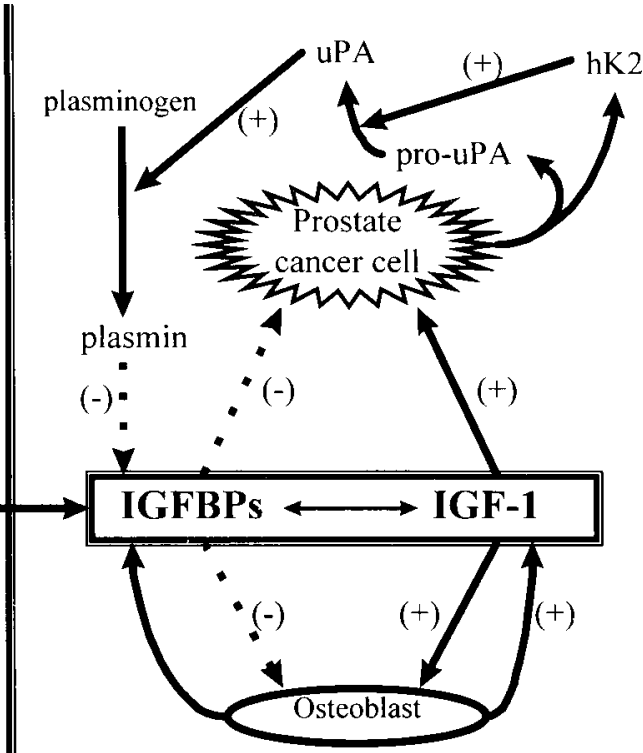

Paracrine loop
Fig. 1. Cell-to-cell interactions involving metastatic prostate cancer and osteoblasts in the microenvironment of osteoblastic metastases. Note the pivotal role of urokinasetype plasminogen activator (uPA)/insulin-like growth factor-binding proteins (IGFBPs)/IGF-1 bioregulation system, which is capable of

tates apoptosis of prostate cancer cells in vivo (53). Therefore, at the cellular level, refractoriness to androgen ablation therapy corresponds to the fact that prostate cancer cells are rescued from androgen ablation-induced apoptosis $(3,18,53)$. This explains why prostate cancer patients initially respond to androgen ablation therapies, but the objective clinical response to hormonal ablation therapy is, unfortunateley, not long-lasting (7-10). Bone metastases are the first and often the only sites of disease which eventually become hormone-refractory $(3,7)$. This occurs at the time when hormone ablation therapy continues to offer sustained control of the disease at the primary site, the prostate and other extraskeletal sites, such as pulmonary metastases $(51,54)$. The sitespecific nature of this refractoriness implies that local environmental cues at the bone may be responsible for rescuing prostate cancer cells from hormonal therapy-induced apoptosis $(3,18,51,53)$. affecting both the growth of metastatic cancer cells and osteoblasts (blastic reaction). In addition, note the potential regulation of IGFs at the site of osteoblastic metastases by growth hormone (GH). GHRH, GH-releasing hormone; hK2, human kallikrein 2.

The production of growth factors by various cells of the bone microenvironment offer a vast spectrum of candidate factors that might mediate this survival effect. Although their role as mitogens for osteoblasts and metastatic cancer cells has been thoroughly investigated (13-15), it is unclear to what extent they could mediate in vivo a significant anti-apoptotic effect as well. To address this question, we first assessed whether osteoblast-derived growth factors and osteoblast CM could rescue prostate cancer cells from chemotherapy-induced apoptosis in vitro. Particular focus was placed on IGF-1, given the cardinal role of the uPA/plasmin/IGF paracrine regulatory pathway in the establishment of the osteoblastic reaction (Fig. 1). Indeed, IGF-1, MG-63 CM and TGF $\beta 1$ partially neutralized the adriamycin-induced cytotoxic death of PC-3 cells. IGF-1 provided the most potent protective effect and also induced additive protection with TGF $\beta 1$ and MG-63 CM. (18). Similar results were obtained from 
experiments employing estrogen receptor negative (ER-) MDA-MB 231 human breast cancer cells (19). These data documented the ability of osteoblast-related growth factors, particularly IGF-1, to protect prostate and breast cancer cells from chemotherapy-induced apoptosis (18-20).

The search for a more comprehensive understanding of interactions between osteoblasts and prostate cancer cells prompted the employment of a three-dimensional (3-D) type I collagen gel cell culture system that allowed the co-culture of human osteoblast-like cells (such as MG-63, Saos-2) with human prostate cancer cells (such as PC- 3 cells) $(55,56)$. In this system, inoculations of human PC-3 cells produced a local osteoblastic reaction, documented by the increased number of MG-63 cells and increased density of type I collagen around the MG-63 cells that were adjacent to inoculated PC-3 cells (55). In contrast, under identical experimental conditions, cell-free medium, human breast cancer cells, endometrial adenocarcinoma cells and lung cancer cells did not produce this blastic reaction (56). In this 3-D system, exposure of PC-3 prostate cancer cells to adriamycin ( $100 \mathrm{nM}$ for $48 \mathrm{hr}$ ) produced massive apoptosis; whereas, exogeneous IGF-I administration and co-culture of PC-3 cells with MG-63 osteoblasts neutralized adriamycin-apoptosis. Therefore, this 3-D model confirmed that human osteoblasts and exogenous IGF-1 rescued human prostate cancer cells from adriamycin-induced apoptosis (18). Apparently, local growth factors known for their role in the pathophysiology of blastic reaction to the presence of prostate tumor cells were also implicated in the development of cytotoxic drug-resistant prostate tumor growth in vitro (18).

The finding that IGF-1 protected prostate cancer cells from apoptosis was consistent with concurrent work from other groups which indicated that the type I IGF-receptor signal transduction mechanism could both induce proliferation and activate intracellular antiapoptotic pathways in breast cancer cells (57-60). The type I IGF-receptor-mediated signaling pathway transduction inhibited etoposide (a topoisomerase I inhibitor)-induced apoptosis, by a mechanism independent of IGF's mitogenicity (60). The anti-apoptotic effect of IGF-1, which was associated with upregulated $B c l-X_{L}$ expression, was mediated by phosphatidylinositol-3'-kinase (PI3'-kinase) and mitogen-activated protein kinase (MAPK) activity, suggesting that IGF-1 was capable of preventing apoptosis by activation of multiple signal transduction pathways, thus, regulating the expression of anti-apoptotic genes, such as $b c l-2$ and $b c l-X_{L}(61,62)$.

In addition to the cardinal role of IGF- 1 as a survival factor, a broad spectrum of other factors may also protect metastatic cancer cells from apoptosis. For example, TGF- $\beta 1$ is protective for both prostate (18) and breast cancer cells (19). The physiological role of some of these growth factors (e.g., IGFs in myeloma) or cytokines (e.g., IL-6) is well established (63). The rapidly growing study of these factors led to the introduction and wider acceptance of the term "survival factors" $(18,19)$. Initially, studies of survival factor mechanism of action focused on mitogenic pathways. A novel concept is that survival factors may act by activating proliferation and by blocking apoptosis. Each of them may occur via distinct signal transduction pathways.

The concept of survival factors is also very important from a clinical standpoint, because it places emphasis on the under-appreciated observation that, at the molecular level, resistance to chemotherapy can be attributed to neither up-regulation of multiple drug-resistant (MDR)-1/P-glycoprotein (or other similar drug transport systems) nor gene amplification mechanisms of chemoresistance $(1,3,64)$. This frequently present, yet poorly understood form of acquired, non-genetic, multidrug-resistant phenotype may be explained, at least in part, by exposure of cancer cells to survival factors locally. It is possible that tissues rich in IGF-I or other survival factors, such as bone, may be sanctuaries for prostate tumor cells. This may account for the switch of prostate cancer cells from an androgen-dependent to an androgenindependent phenotype, while the cells still possess androgen receptor.

Until fairly recently, the prevailing hypothesis was that androgen receptor (AR) gene expression defects were the most likely molecular basis of refractoriness to androgen ablation (65). However, down-regulation or loss of AR expression has not been documented in androgen-independent prostate cancer (66, 67). This is consistent with the possibility that other mechanisms might be involved for the phenotypic switch to androgen insensitivity. Indeed, certain point mutations at the AR ligand-binding domain produce broad ligand- 
binding specificity, creating mutant ARs with transcriptional activity that paradoxically can be activated by steroids other than androgen or even by antiandrogens (68-70). This is the molecular background of the anti-androgen withdrawal syndrome $(71,72)$. Alternatively, prostate cells with amplification of the AR gene may respond to very low concentrations of androgens, which might, in theory, explain the disease progression to stage $\mathrm{D} 3$ during androgen ablation therapy $(73,74)$. Furthermore, AR mutations that constitutively activate ARregulated pathways would, at least theoretically, explain the ability of prostate cancer cells to survive in an environment lacking its ligand (75). All the aforementioned mutations are fairly frequent (76), but they have been identified in only a subgroup of tumor samples from hormone refractory patients (77-84). Therefore, it is conceivable that other molecular events might mediate AR-regulated transcription of genes acting during cellular apoptosis, even under conditions in which concentrations of the androgen are suppressed (85).

Since the androgen-AR signaling pathway is essentially a survival factor pathway, it is conceivable that growth factor signaling pathways can meet and cross-communicate with particular checkpoints of the intracellular molecular pathway of apoptosis $(86,87)$. One of the first molecular cross-talk connections identified involved serine phosphorylation of the death agonist $\mathrm{Bad}(88)$. The phosphorylated Bad protein binds the cytosolic protein p14-3-3, which prevents $\mathrm{Bad}$ from forming heterodimers with the anti-apoptotic factors $b c l-x L$ and $b c l-2$ (89). Consequently, survival factors with signal transduction pathways that can phosphorylate the Bad protein will shift the balance between pro-apoptotic (e.g. Bad, Bax, Bik, Bcl- $X_{S}$ ) vs. anti-apoptotic $\left(b c l-2, b c l-X_{L^{\prime}}\right)$ bcl-2 family members toward the direction of blockade of apoptosis (90). Increasing evidence points out that growth factors can indeed activate such ARregulated, anti-apoptotic genes through intracellular signal transducers, such as CAMP, protein kinase A and protein kinase C (91). IGF-1, keratinocyte growth factor (KGF) and epidermal growth factor (EGF) stimulate AR transcription in the DU-145 cancer cell line (92); whereas, LNCaP cells exposed to IGF-1 remarkably increase the AR-mediated expression of PSA (93). Therefore, growth factor signaling pathways may cross-talk with the AR-regulated, anti-apoptotic pathways in both mutant and wild-type AR, while the mutantAR may be activated more efficiently by polypeptide growth factors than the wild-type AR $(92,93)$. The latter may account for the association of AR mutations with poor prognosis, as reported in clinical series (92). Moreover, it recently was shown that natural hormones with low-level androgenic activity, such as delta-(5)-androstenediol were not completely blocked by the anti-androgens used in conventional androgen ablation therapies, such as hydroxyflutamide and bicalutamide. It appeared that minimal androgenic activity of such compounds, although insufficient to reverse the lack of major, potent AR ligand, could potentially provide a baseline level of AR-transactivation that was potentiated by cross-talking growth factor signaling pathways (94).

Therefore, the presence of appropriate survival factor stimuli, such as that from IGF-I in bone, can compensate for the lack of androgen support during ablation therapy in the metastatic prostate cancer cells. In addition, molecular mechanisms, including the enhancement of cell anti-apoptosis function, release of cell cycle inhibition and stimulation of cell proliferation (95), that mainly involve tyrosine kinase overexpression in metastases have been associated with rapid evolution of the disease. The cross-talk of these growth factors (especially, IGF-1/tyrosine kinase pathways) with the AR-signaling cascade up-regulates the expression of anti-apoptotic genes, such as $b c l$ 2 and $b c l-X_{L}$. These genes are involved not only in the progression to hormone refractory stage D3, but in chemotherapy-resistant tumor growth, as well (93). This is consistent with both our in vitro data (18) and with the clinical observation that hormone-refractory patients have minimal, if any, responses to chemotherapy. Conceivably, chemotherapy-induced apoptosis is abrogated by the same survival factor pathway that is responsible for confering resistance to hormonal therapy in the first place. $(18,19)$. The role of IGF-1 in hormonerefractoriness may also be reflected in the recent finding of cDNA microarray studies in nude mice xenografts of human hormone refractory prostate cancer samples. Hormonerefractory xenografts appear to overexpress the IGFBP-2 gene that participated in the regulation of the local bioavailability of IGF. This finding, if confirmed, may reflect a compensatory mechanism of the tumor's stroma to 
(down)-regulate the increased bioavailability of IGF-1 locally (96).

\section{Development of an Anti-survival Factor (ASF) Therapy for Hormone- refractory and Chemotherapy- resistant Metastatic Prostate Cancer}

The analysis of molecular mechanisms that can control IGF-1 bioavailability in bone metastases was greatly enhanced by documentation of the presence and functional integrity of glucocorticoid receptor (GR) in human and rat prostate cancer cells $(36,48,97)$, as well as the analysis of GR function in cell-to-cell interactions between prostate cancer and osteoblastlike cells (36). Dexamethasone inhibits the proliferation of androgen-insensitive rat PA-III and human PC-3 prostate cancer cells $(48,97)$, while it decreases the osteoblast-derived IGFs $(49,98,99)$. Dexamenthasone also downregulates prostate cancer cell expression of uPA (100), subsequently, it causes a reduction of the uPA-mediated hydrolysis of IGFBPs, increasing IGFBPs concentration. Consequently, the increased IGFBPs concentration reduces the bioavailability of IGFs to both prostate cancer cells and osteoblasts locally $(33,47)$. At the same time, the pro-apoptotic effect of IGFBP-3 is increased (50). The aformentioned mechanisms lead to the regression of PA-III prostate cancer-cell induced tumors in rat bones following high-dose dexamethasone therapy (100).

The role of glucocorticoids may extend beyond IGF-1. Interleukin-6 (IL-6), a multifunctional cytokine produced by bone marrow stromal cells $(101,102)$, osteoclasts (103), and osteoblasts (104), is also down-regulated by glucocorticoids (105-107). It is noteworthy that IL-6 also confers resistance against cisplatin and etoposide cytotoxicity in PC-3 and DU-145 prostate cancer cells (108); whereas, serum IL-6 levels are elevated significantly in hormone-refractory prostate cancer patients, indicating a possible role of IL-6 in the hormone refractory phenotype in vivo (109). Therefore, the molecular effects of dexamethasone on the host tissue and prostate cancer cells, as well as on reciprocal cell-to-cell interactions suggest a potentially therapeutic involvement of glucocorticoids in bone metastases from prostate cancer (100).

This anti-IGF-oriented rationale for the administration of glucocorticoids is a novel con- cept, totally different from the previously reported uses of glucocorticoid in the prostate cancer literature (110-119). In these studies, the administration of glucocorticoids was either empirically attempted or constituted a glucocorticoid replacement therapy in aminoglutethimide-induced "medical adrenalectomy," attempting what was hoped to be a more complete androgen blockade for prostate cancer. Objective responses (with a rate of $10-20 \%$ ) and/or transient symptomatic improvement were recorded in some cases $(118,119)$. The discrepancy between these results and the efficacy that one might predict based on the in vitro effectiveness of dexamethasone to block IGF-1 probably was explained by the existence of extra-skeletal sources of IGF-1, notably from the liver. Glucocorticoids can locally downregulate osteoblast-derived IGF-1, but this effect is eventually neutralized by the incoming influx of circulating, growth hormone (GH)dependent, liver-derived IGF-1 (120,121). Therefore, even though dexamethasone's administration is still necessary to sustain the down-regulation of local osteoblast-derived IGF- 1 production, it cannot neutralize extraskeletal bioavailability of IGFs, unless appropriate blockade of $\mathrm{GH}$-dependent hepatic production of IGFs is attempted.

Recently, patients with GH-secreting pituitary adenomas who received long-acting somatostatin analogs, such as lanreotide, experienced remarkable clinical improvement associated with a decrease in circulating, GHdependent IGF-1 (122) and an increase in circulating IGFBP-1 (123). Minimal side effects were documented in these clinical trials, such as abnormal oral glucose tolerance test, increased blood glucose, moderate elevations of blood pressure, cholestasis, constipation, etc., all of which were well-managed medically $(122,123)$. These data prompted us to incorporate both dexamethasone and somatostatin analogs into our therapeutic protocol, aiming to decrease IGF-1 bioavailablity to prostate cancer cells.

In the past, somatostatin analogs were evaluated in clinical trials for advanced stage prostate cancer. However, the rationale for administering these compounds was to produce either a somatostatin receptor-mediated antiproliferative or pro-apoptotic effect on metastatic cancer cells, or to achieve a selective targeting of somatostatin receptor-positive cancer cells using cytotoxic compounds linked to so- 
matostatin analogs (124-130). The lack of a significant therapeutic benefit from the use of somatostatin analogs alone, underlines the importance of both endocrine (GH-dependent, liver-derived) and paracrine (osteoblastderived) IGF-1 production. Within this context, monotherapy of somatostatin analogs fails to offer a complete survival factor ablation in bones. Osteoblast-derived IGFs are not abrogated by somatostatin analogs, but rather by glucocorticoid-mediated down-regulation of IGF-1 and prostate cancer cell-derived, uPAmediated, increase of IGF-1 bioavailability locally (Fig. 1). Therefore, a complete anti-IGF therapeutic scheme (Fig. 2) should include both glucocorticoid administration and somatostatin analog therapy. We previously named this anti-IGF-I therapy "anti-survival factor (ASF) therapy (131)."

\section{Application of ASF Therapy In Hormone Refractory/ Chemotherapy-resistant Prostate Cancer}

In our institution, the ASF therapy is tested in a phase II clinical protocol as an adjuvant thera- peutic strategy (131). It is important to clarify that ASF therapy is not an anti-cancer therapy per se, but a modality designed to enhance the effectiveness of existing therapeutic regimens. Therefore, the novel concept of combination therapy should include ASF therapy and an anti-cancer therapy (Fig. 3). Consequently, in our phase II trial, the novel concept of ASF therapy was tested in combination with hormone ablation therapy, employing terminally ill prostate cancer patients who had: (a) progressed to stage $\mathrm{D} 3$ while on combined androgen blockade (CAB; GnRH-A plus flutamide); (b) did not respond to anti-androgen withdrawal manipulation; and (c) had also failed to respond to salvage chemotherapy. Our ASF therapy included administration of dexamethasone (4 mg, tapered down to $2 \mathrm{mg}$ qD within 3 months), plus somatostatin analog (somatuline; lanreotide; $30 \mathrm{mg}$, i.m., q14D) in combination with hormone ablation therapy (GnRH-A; triptorelin, 3,75 mg, i.m., q28D) with or without antiandrogen (flutamide 250, tid, p.o.), depending whether these stage D3 patients showed a response to antiandrogen withdrawal (131). Ten prostate cancer patients with diffuse bone metastases and hormonerefractory and chemotherapy-resistant disease entered this trial.

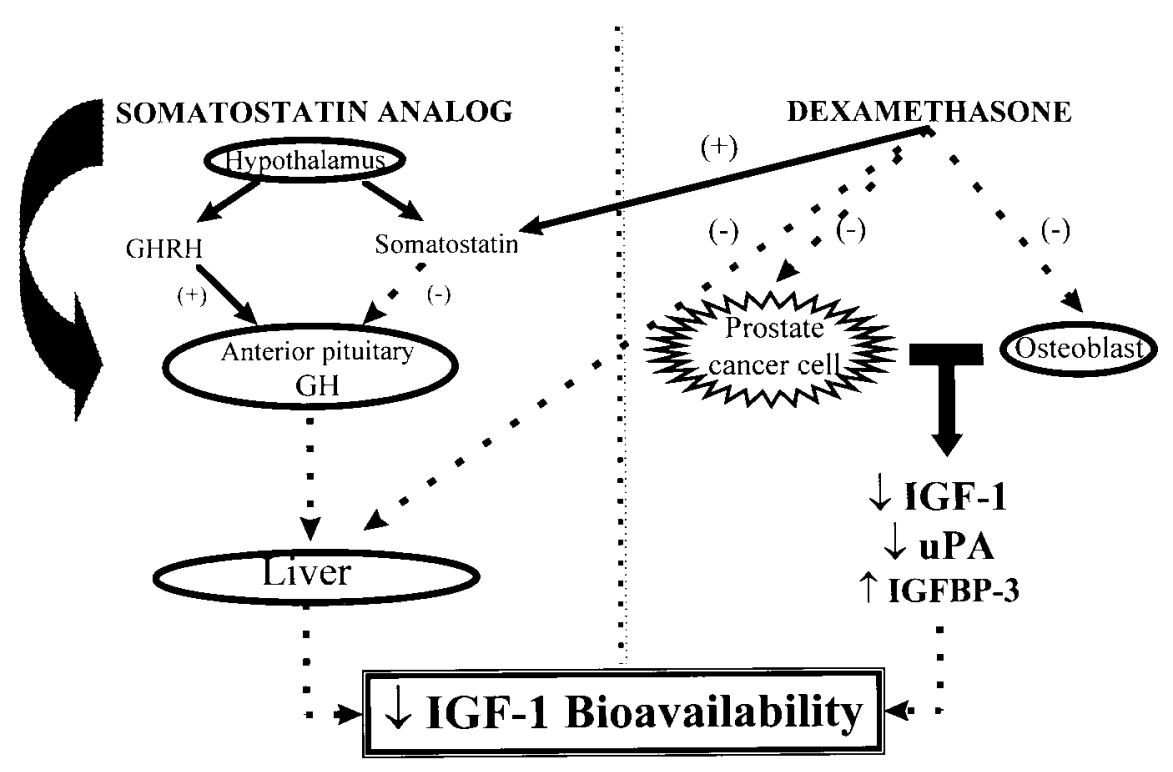

Endocrine loop

Fig. 2. Development of an anti-survival factor therapy (ASF therapy). Development of ASF therapy focuses on the endocrine, growth hormone (GH)-dependent liver-derived, and paracrine, osteoblast-derived, IGF-1 bioavailability that can be
Paracrine loop

abrogated by somatostatin analogs and dexamethasone, respectively. GHRH, GH-releasing hormone IGF- 1 = insulin-like growth factor-1; IGFBP-3 = insulin-like growth factor binding protein-3; uPA = urokinase-type plasminogen activator. 
With the exception of one patient with continuous rise in PSA levels, despite ASF, all other patients responded to this combination therapy (follow-up to 4 months). Two had a complete clinical response, with normalization of PSA (PSA $<4.0 \mathrm{ng} / \mathrm{ml}$ ), followed by a remarkable improvement of their performance status. Four others had partial response (decreasing PSA values below $50 \%$ of baseline) in which they experienced a definite improvement of performance status (physical activity, consumption of analgesics). Three other patients experienced a stable response, as documented by decreasing PSA levels to less than $50 \%$ of their initial values and they improved their performance status. Finally, one patient, despite marked improvement of bone pain and physical acitivity, continued to have a rise in his PSA levels for 4 months. Figures 4 and 5 demonstrate two representative examples of patients who responded to the combination of ASF with hormone ablation therapy, with an improvement in performance status and a reduction in PSA levels. Although still at a preliminary phase, the ASF therapy showed efficacy for re-introducing objective clinical responses in patients with hormone refractory disease.

In view of these facts, the novel approach of ASF, albeit on initial responses in this pilot study, is very encouraging because it produced clinical responses, some of them remarkable, in patients who had practically failed every avail- able conventional treatment option, including salvage chemotherapy. The ASF therapy reintroduced sensitivity to hormonal therapy, resulting in objective responses that may be durable. Such reversal of resistance to hormonal therapy has not been achieved by any other regimen, to our knowledge. Moreover, this important effect was not associated with any severe side effects to either dexamethasone or somatostatin analogs (131). Therefore, the novel concept of ASF therapy in combination with hormone ablation therapy is of clinical significance and merits further testing as a palliative approach regarding its efficacy, efficiency and its effect on quality of life, in comparison to salvage chemotherapy, in a randomized controlled trial setting for patients early in the progression to stage $\mathrm{D} 3$.

\section{Perspectives of ASF Therapies Beyond Prostate Cancer}

Obviously, the local bone microenvironment may serve as an inhibitor of intracellular proapoptotic pathways of tumor cells, not only in prostate cancer metastases, but also with other osteotropic malignancies. Indeed, human osteoblast-like MG-63 cells, MG-63 conditioned media, IGF- 1 and TGF- $\beta 1$ can alter the effects of adriamycin on cell cycle and apoptosis of estrogen receptor negative (ER-) MDA-MB231 (19) and estrogen receptor positive (ER+)

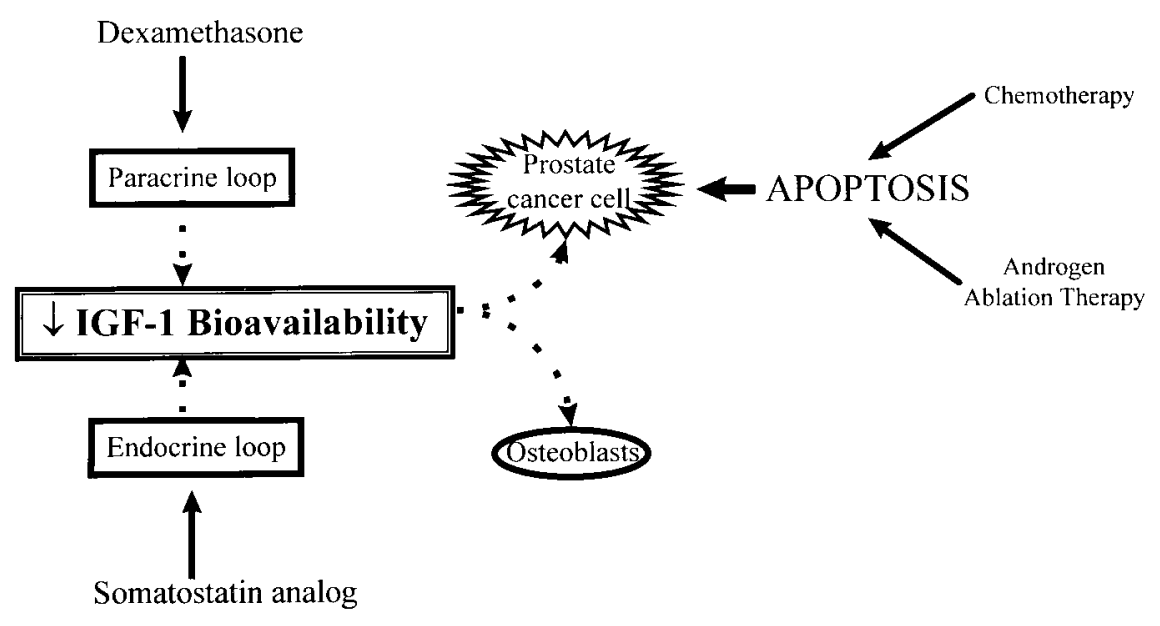

Fig. 3. The novel concept of combination therapy. Combination therapy employs the antisurvival factor (ASF) therapeutic approach and anti-cancer therapies, such as androgen ablation therapy or cytotoxic chemotherapy. IGF-1 = insulin-like growth factor-1. 


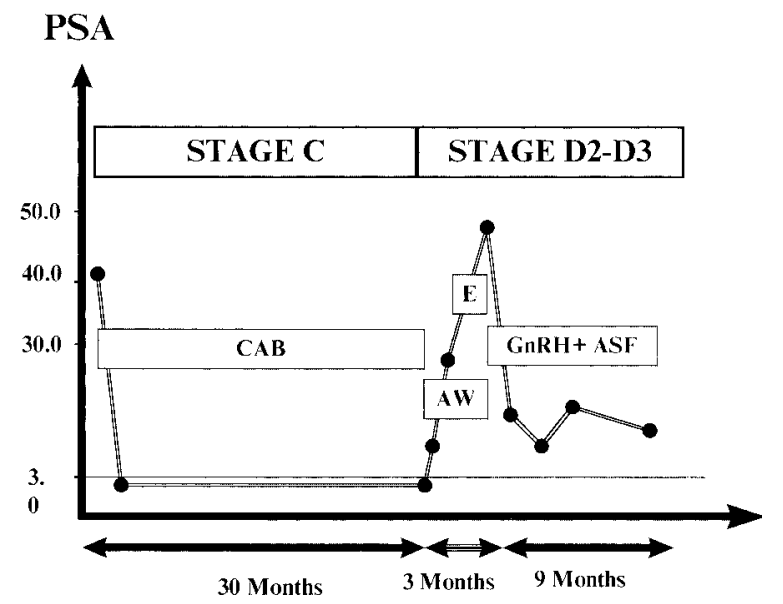

Fig. 4. Patient with stage $C$ prostate cancer response to androgen blockade. The response (as presented by the follow-up of PSA values) in a patient with stage $C$ prostate cancer who was treated with complete androgen blockade (CAB) (GnRH-A; triptorelin 3,75 mg i.m. q28D, plus flutamide $250 \mathrm{mg}$ tid, p.o.) for 30 months before progressing to stage D3 hormone refractory prostate cancer with concurrent development of multiple osteoblastic bone metastases. Anti-androgen (flutamide) withdrawal (AW) did not produce a clinical response and administration of estramustine phosphate (E) $3 \times 140 \mathrm{mg}$ tid, p.o., in combination with GnRH-A also failed to arrest disease progression. The patient received combination therapy using anti-survival factor therapy [(ASF) dexamethasone $4 \mathrm{mg}$, p.o. qD, tapered to $2 \mathrm{mg}$ qD within 3 months and somatostatin analog (lanreotide $30 \mathrm{mg}$ i.m. q14D)] while continuing on GnRH-A (triptorelin, 3,75 mg i.m. q28D). This patient experienced a partial clinical response (decrease of PSA more than $50 \%$ and significant improvement of clinical symptoms-pain and analgesics consumption). GnRH, gonadotropin releasing hormone; PSA, prostate-specific antigen.

MCF-7 breast cancer cells (20). Adriamycin arrested MCF-7 and MDA-MB-231 cells at the G2/M phase in the cell cycle and inhibited cell growth. In addition, adriamycin arrested the MCF-7 cells at the G1/G0 phase and induced apoptosis of MDA-MB-231 cells. Exogenous IGF-1 partially neutralized the adriamycincytotoxicity/cytostasis of MDA-MB-231 cells. MG-63 conditioned media and TGF- $\beta 1$ partially neutralized the adriamycin-induced cytotoxicity of MDA-MB-231 cells, but enhanced adriamycin-induced blockade of MCF-7 cells at the G1/G0 phase. MG-63 osteoblast-like cells inhibited growth of MCF-7 cells, while it promoted growth and rescued the MDA-MB-231 cells from adriamycin-induced apoptosis in a type I collagen co-culture system. These data suggest that osteoblast-derived IGF- 1 and TGF- $\beta 1$ modify the response of breast cancer cells to cytotoxic chemotherapy $(19,20)$.

In addition, IL- 6 has a well-established role as a growth factor for human multiple myeloma cells via phosphorylation of the retinoblastoma protein $(\mathrm{Rb})$, thereby, facilitating transition from the Gl to the $S$ phase of the cell cycle (132-134). Moreover, bone marrow stromal cells from patients with multiple myeloma express viral IL-6, a functional homolog of human IL-6, produced by Kaposi's sarcomaassociated herpes virus and may further enhance myeloma cell growth and survival (135). Bone marrow stromal cells up-regulate, via NF $\kappa$ B activation, the production of IL- 6 in response to adhesion of myeloma cells (136). IL-6, aside from its stimulatory role for myeloma cell proliferation, is a survival factor that inhibits apoptosis to corticosteroids (137), serum starvation (138) and cross-linking of the tumor necrosis factor (TNF)-receptor superfamily member Fas (CD95/Apo-1) (139). The survival factor effect of IL-6, a product of a glucocorticoid receptor-regulated gene, on myeloma cells has been attributed, at least in part, to a (Janus kinases/Signal tranducers and activators of transcription) JAK/STAT-mediated pathway, involving especially STAT-3 and leading to elevated levels of the anti-apoptotic protein Bcl$\mathrm{X}_{\mathrm{L}}$ (140). IGF-1 was shown to function both as a growth and survival factor for myeloma cells $(63,141,142)$, raising the possibility that the addition of somatostatin analogs (decreasing GHmediated, liver-derived IGF-1) in currently used chemotherapeutic regimens that generally contain glucocorticoids might yield a potential therapeutic benefit.

The system of IGFs/type I IGF receptor (IGF-R)/IGFBPs is implicated in the establishment and progression of liver metastases in certain malignancies, such as colorectal cancer (143). The highly metastatic and preferentially hepatotropic phenotype of the $\mathrm{H}-59$ subline of the Lewis lung carcinoma is secondary to the significantly higher expression of type I IGF-R of H59 cells, compared with another subline, M-27, that metastasizes only to the lung. The highly mitogenic activity, preferential for H-59 cells and not M-27 cells, of serum-free, conditioned-media from primary mouse hepatocyte cultures was blocked or depleted by a monoclonal antibody to IGF-1 (144). In addition, transfection of an antisense construct for the type I IGF-R in $\mathrm{H}-59$ cells completely blocked responsiveness to IGF-1 and prevented the 


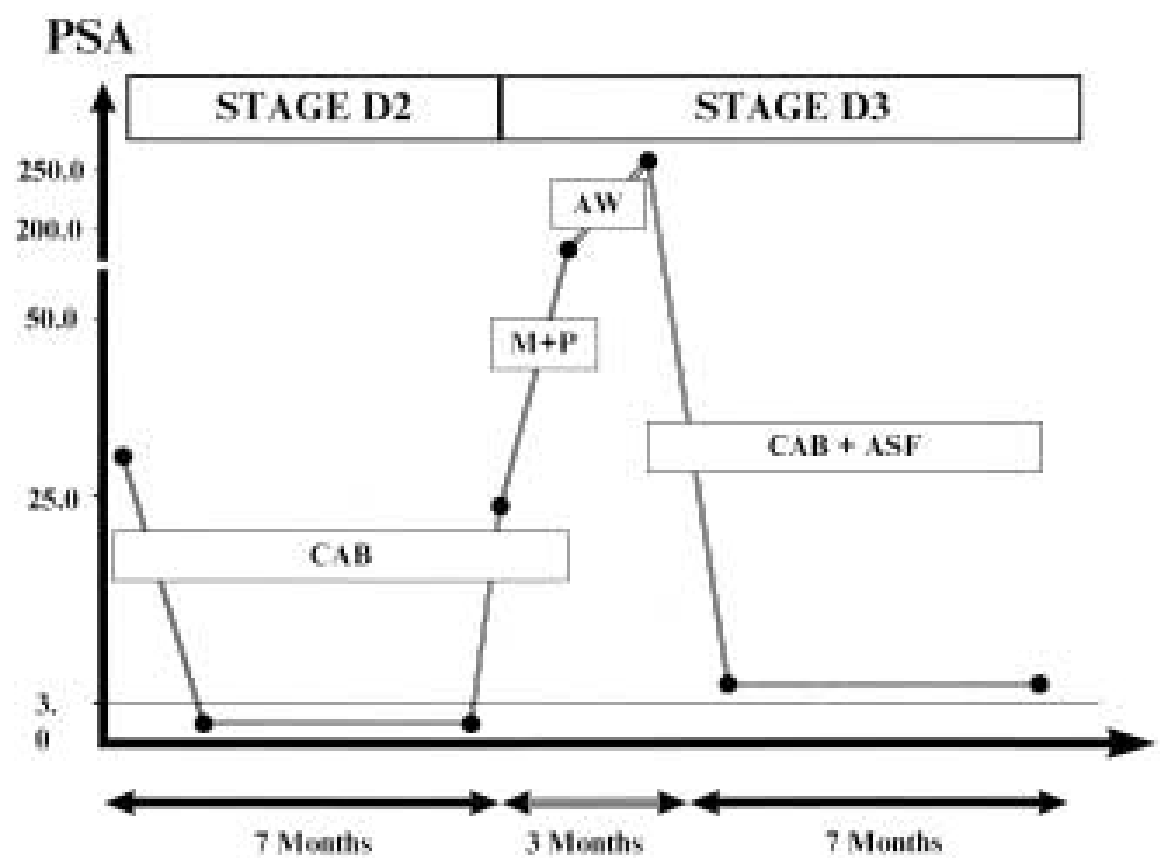

Fig. 5. Patient with stage D2 prostate cancer response to complete androgen blockade. The clinical response (as presented by the follow-up of PSA values) in a patient with stage D2 prostate cancer who was treated with complete androgen blockade [(CAB) GnRH-A; triptorelin 3,75 mg i.m. q28D plus flutamide; $250 \mathrm{mg}$ tid p.o.] for 7 months before he progressed to stage D3, hormone refractory, prostate cancer. $\mathrm{CAB}$ plus salvage chemotherapy $(\mathrm{M}+\mathrm{P})$, employing mitoxantrone (10 mg/M2, i.v. q3 weeks) and prednisolone (10 mg, i.m., qD for the

establishment of liver metastases in vivo (145); whereas, overexpression of the type I IGFreceptor enhanced the metastatic phenotype, facilitating invasion and liver colonization (146). Moreover, the efficacy of tamoxifen in breast cancer treatment was postulated to be related, at least in part, to reduced bioavailability of IGF-1 to cancer cells (147). It is, therefore, rational to further explore potential applications of the concept of anti-survival factor therapy in hepatic metastases and other metastatic sites of IGF-1-dependent malignancies, such as ovarian cancer $(148,149)$.

\section{Conclusions}

The paradoxical symbiosis of prostate cancer cells with osteoblasts results in an anatomical situtation where metastatic cell-derived mitogen(s) stimulate osteoblasts to produce a blastic reaction, with the trade-off that osteoblast secretagogues support the efforts of the metastatic cells to escape apoptosis and optimize first week in each cycle) produced no response. Moreover, flutamide withdrawal (AW) did not affect disease progression. Patient was put on combination therapy using anti-survival factor therapy [(ASF) dexamethasone $4 \mathrm{mg}$ p.o. $\mathrm{qD}$, tapered to $2 \mathrm{mg} \mathrm{qD}$ within 3 months] and somatostatin analog (lanreotide $30 \mathrm{mg}$, i.m., q14D)] and GnRH-A (triptorelin, 3,75 mg i.m. q28D). This patient experienced an impressive clinical response (decrease of PSA to normal values and excellent performance status). $(18,19)$ PSA $=$ prostate-specific antigen.

their survival. For these two reciprocal intercellular interactions between cancer cells and osteoblasts, it is documented that IGF-1 is the major mediator, although other survival/ growth factors conceivably could participate. Our bench-to-bedside development of an ASF therapy was not designed to stand alone when fighting advanced stage prostate cancer. In fact, ASF was developed to enhance the efficacy of existing anti-cancer therapies. Although not the only bone-derived cancer cell survival factor, IGF- 1 is the main target for the ASF therapy. We caution that the biologic redundancy and flexibility of tumor cells are expected to exploit other intercellular communications and intracellular pathways to evade apoptosis. Even in that case, however, the concept of an ASF therapy already has offered significant benefits both to our patients, adding a low-toxicity weapon that enhances the efficacy of existing therapeutic modalities, and to our understanding of neoplasia and metastasis. This novel ASF concept indicates that our focus should be placed not 
only on the effect of a tumor on its host tissue, but also on the effect of the host tissue on the tumor biology.

\section{Acknowledgments}

Dr. Michael Koutsilieris and associates currently are funded by the General Secretariat of Research \& Technology (GGET), Ministry of Energy and Industry, Greece; Central National Council of Health, Ministry of Health, Greece (KESY); Research Funds, University of Athens, Ministry of Education, Greece; IPSEN Pharmaceuticals, Hellas S.A., and Endo/OncoResearch Laboratories, Athens, Greece.

\section{References}

1. Tannock IF. (1985) Is there evidence that chemotherapy is of benefit to patients with carcinoma of the prostate? J. Clin. Oncol. 3: 1013-1021.

2. Hudes GR. (1992) Phase II study of estranustine and vinblastin, two inhibitors in hormonerefractory prostate cancer. J. Clin. Oncol. 10: 1754-1761.

3. Koutsilieris M, Dimopoulos MA, Doillon C, Sourla A, Reyes-Moreno C, Choki I. (1996) The molecular concept of prostate cancer. Cancer J. 9: 89-94.

4. Belliveau RE, Spencer RP. (1975) Incidence and staging of bone lesions detected by $99 \mathrm{mTc}$ polyphosphate scans in patients with tumors. Cancer 36: 65-72.

5. Galasko CS. (1976) Mechanisms of bone destruction in the development of skeletal metastases Nature 263: 507-508.

6. Galasko CS. (1982) Mechanism of lytic and blastic metastatic disease of bone Clin. Orth. 12: 20-27.

7. Koutsilieris M, Faure N, Tolis G, Laroche B, Robert G, Ackman CF. (1986) Objective response and disease outcome in 59 patients with stage D2 prostatic cancer treated with either Buserelin or orchiectomy. Disease aggressivity and its association with response and outcome. Urology 27: 221-228.

8. Koutsilieris M. Laroche B, Thabet M, Fradet Y. (1990) The assessment of disease aggressivity in stage D2 prostate cancer patients (review). Anticancer Res. 10: 333-336.

9. Crawford ED, Eisenberger MA, McLeod DG, et al. (1989) A controlled trial of leuprolide with and without flutamide in prostatic carcinoma N. Engl. J. Med. 321 : 419-424.

10. Koutsilieris M. (1993) Osteoblastic metastasis in advanced prostate cancer. Anticancer Res. 13: 443-449.
11. Raghavan D, Wallace M. (1990) Preemptive (neoadjuvant) chemotherpy: can analysis of eligibility criteria, prognostic factors, and tumour staging from different trials provide valid or useful comparisons? Semin. Oncol. 17: 613-618.

12. Tolis G, Koutsilieris M, Fazekas ATA, Patton R. (1983) Transabdominal ultrasonography in the evaluation of patients with advanced prostatic carcinoma. Effects of castration and of chronic administration of a gonadotropin releasing hormone agonistic analogue. Prostate 4: 595600 .

13. Mundy GR, (1997) Mechanisms of bone metastasis. Cancer 80: 1546-1556.

14. Jacobs SC, Pinka D, Lawson RK, (1988) Prostatic osteoblast factor. Invest Urol. 17: 195-199.

15. Guise TA, Mundy GR. (1998) Cancer and bone. Endocr. Rev. 19: 18-54.

16. Koutsilieris M, Rabbani SA, Goltzman D. (1986) Selectice osteoblast mitogens can be extracted from prostatic tissue. Prostate 9: 109115.

17. Koutsilieris M, Rabbani SA, Goltzman D. (1987) Effects of human prostatic mitogens on rat bone cells and fibroblasts. J. Endocrinol. 115: 447-454.

18. Reyes-Moreno C, sourla A, Choki I, Doillon C, Koutsilieris M. (1998) Osteoblast-derived survival factors protect PC-3 human prostate cancer cells from adriamycin apoptosis. Urology 52: 341-347.

19. Koutsilieris M, Reyes-Moreno C, Choki I, Sourla A, Doillon C, Pavlidis N. (1999) Chemotherapy-cytotoxicity of human MCF-7 and MDA-MB 231 breast cancer cells is altered by osteoblast-derived growth factors. Mol. Med. 5: 18-29.

20. Choki I, Sourla A, Reyes-Moreno C, Koutsilieris M. (1999) Osteoblast-derived growth factors enhance adriamycin-cytostasis of MCF-7 human breast cancer cells. Anticancer Res. 18: 4213-4224.

21. Polychronakos C, Janthly U, Lehoux JG, Koutsilieris M. (1991) Mitogenic effects of insulin and insulin-like growth factors on PA-III rat prostate adenocarcinoma cells: characterization of the receptors involved. Prostate 19: 313-321.

22. Koutsilieris M. (1988) Prostate-derived growth factors for bone cells: implications for bone physiology and pathophysiology: review. In Vivo 2: 377-383.

23. Steiner MS, Barrack ER. (1992) Transforming growth factor- $\beta 1$ overproduction in prostate cancer: effects on growth in vivo and in vitro. Mol. Endocrinol. 6: 15-25.

24. Matuo Y, Nishi N, Matsui S, Sandberg AA, Isaacs JT, Wada F. (1987) Herparin binding affinity of rate prostate growth factor in normal and cancerous prostate: partial purification and 
characterisation of rate prostatic growth factor in the Dunning tumor. Cancer Res. 47: 188-192.

25. Nishikawa K, Yoshitake Y, Minemura M, Yamada K, Matuo Y. (1992) Localization of basic fibroblast growth factor (bFGF) in a metastatic cell line (AT-3) established from the Dunning prostatic carcinoma of rat: application of a specific monoclonal antibody. Adv. Exp. Med. Biol. 324: 131-139.

26. Mansson PE, Adams P, Kan M, McKeehan WL. (1989) HBGFl gene expression in normal rat prostate and two transplantable rat prostate tumors. Cancer Res. 49: 2485-2494.

27. Chen D, Feng JQ, Feng M, et al. (1995) Sequence and expression of bone morphogenetic protein 3 mRNA in prolonged cultures of fetal rat calvarial osteoblasts and in rat prostate adenocarcinoma PA III cells. DNA Cell Biol. 14: 235-239.

28. Harris SE, Harris M, Mahy M, Wozney J, Feng J, Mundy GR. (1994) Expression of bone morphogenetic proteins by normal rat and human prostate cancer cells. Prostate 24: 204-211.

29. Langenstroer $P$, Tang R, Shapiro E, Divish B, Opgenorth T, Lepor H. (1993) Endothelin-1 in the human prostate: tissue levels, source of production and isometric tension studies. J. Urol. 151: 495-499.

30. Nelson JB, Hedican SP, George DJ, et al. (1995) Identification of endothelin-1 in the pathophysiology of metastatic adenocarcinoma of the prostate. Nature Med. 1: 944-949.

31. Koutsilieris M, Rabbani SA, Bennett HP, Goltzman D. (1987) Characteristics of prostatederived growth factors for cells of the osteoblast phenotype. J. Clin. Invest. 80: 941-946.

32. Simpson E, Harrod J, Eilon G, Jacobs JW, Mundy GR. (1985) Identification of a messenger ribonucleic acid fraction in human prostate cancer cells coding for a novel osteoblaststimulating factor. Endocrinology 117: 16151619.

33. Koutsilieris $M$, Frenette G, Lazure C, Lehoux JG, Govindan MV, Polychronakos C. (1993) Urokinas-type plasminogen activator: a paracrine factor regulating the bioavailability of IGFs in PA-III cell-induced osteoblastic metastases. Anticancer Res. 13: 481-486.

34. Wun T-C, Assowski L, Reich E. (1982) A proenzyme form of human urokinase. J. Biol. Chem. 257: 7262-7268.

35. Frenette G, Tremblay RR, Lazure C, Dube JY. (1997) Prostatic kallikrein hK2, but not prostate-specific antigen (hK3), activates single-chain urokinase-type plasminogen activator. Int. J. Cancer 71: 897-9.

36. Reyes-Moreno C, Koutsilieris M. (1997) Glucocorticoid receptor function possibly modulates cell-cell interactions in osteoblastic metastases on rat skeleton. Clin. Exp. Metastasis 15: 205-217.
37. Mizukami IF, Garni-Wagner BA, DeAngelo LM, et al. (1994) Immunologic detection of the cellular recptor for urokinase plasminogen activator. Clin. Immunol. Immunopathol. 71: 96-104.

38. Webber MM, Waghray A. (1995) Urokinasemediated extracellular matrix degradation by human prostatic carcinoma cells and its inhibition by retinoic acid. Clin. Cancer Res. 1: 755-761.

39. Crowley CW, Cohen RL, Lucas BK, Liu G, Shuman MA, Levinson AD. (1993) Prevention of metastasis by inhibition of the urokinase receptor. Proc. Natl. Acad. Sci. U.S.A. 90: 5021-5025.

40. Quax PH, de Bart AC, Schalken JA, Verheijen JH. (1997) Plasminogen activator and matrix metalloproteinase production and extracellular matrix degradation by rat prostate cancer cells in vitro: correlation with metastatic behavior in vivo. Prostate 32: 196-204.

41. Achbarou A, Kaiser S, Tremblay G, et al. (1994) Urokinase overproduction results in increased skeletal metastasis by prostate cancer cells in vivo. Cancer Res. 54: 2372-2377.

42. Jankun J, Keck RW, Skrzypczak-Jankun E, Swiercz R. (1997) Inhibitors of urokinase reduce size of prostate cancer xenografts in severe combined immunodeficient mice. Cancer Res. 57: 559-563.

43. Hienert G, Kirchheimer JC, Pfluger H, Binder BR. (1988) Urokinase-type plasminogen activator as a marker for the formation of distant metastases in prostatic carcinomas. J. Urol. 140: 1466-1469.

44. Rabbani SA, Desjardins J, Bell AW, et al. (1990) An amino-terminal fragment of urokinase isolated from a prostate cancer cell line (PC-3) is mitogenic for osteoblast-like cells. Biochem. Biophys. Res. Commun. 173: 1058-1064.

45. Rabbani SA, Mazar AP, Bernier SM, et al. (1992) Structural requirements for the growth factor activity of the amino-terminal domain of urokinase. J. Biol. Chem. 267: 14151-14156.

46. Rabbani SA, Gladu J, Mazar AP, Henkin J, Goltzman D. (1997) Induction in human osteoblastic cells (SaOS2) of the early response genes fos, jun, and myc by the amino terminal fragment (ATF) of urokinase. J. Cell Physiol. 172: 137-145.

47. Koutsilieris M, Polychronakos C. (1992) Proteinolytic activity against IGF-binding proteins involved in the paracrine interactions between prostate adenocarcinoma cells and osteoblasts. Anticancer Res. 12: 905-910.

48. Reyes-Moreno C, Frenette G, Boulanger J, Lavergne E, Govindan MV, Koutsilieris M. (1995) Mediation of glucocorticoid receptor function by transforming growth factor beta I expression in human PC-3 prostate cancer cells. Prostate 26: 260-269.

49. Boulanger J, Reyes-Moreno C, Koutsilieris M. 
(1995) Mediation of glucocorticoid receptor function by the activation of latent transforming growth factor beta 1 in MG-63 human osteosarcoma cells. Int. J. Cancer 61: 692-697.

50. Rajah R, Valentinis B, Cohen P. (1997) Insulinlike growth factor (IGF)-binding protein-3 induces apoptosis and mediates the effects of transforming growth factor-beta 1 on programmed cell death through a p53- and IGFindependent mechanism. J. Biol. Chem. 272: 12181-12188.

51. Koutsilieris M. (1995) Skeletal metastases in advanced prostate cancer: cell biology and therapy. Crit. Rev. Oncol. Hematol. 18: 51-64.

52. Kuratsukuri K, Sugimura K, Harimoto K, Kawashima H, Kishimoto T. (1999) "Decoy" of androgen-responsive element induces apoptosis in LNCaP cells. Prostate 41: 121-126.

53. Landstrom M, Damber JE, Bergh A. (1994) Regrowth after initially succesful castration therapy may be related to decreased apoptotic cell death rate. Anticancer Res. 54: 4281-4284.

54. Behrakis P, Koutsilieris M. (1997) Pulmonary metastases in metastatic prostate cancer: host tissue-tumor cell interactions and response to hormone therapy. Anticancer Res. 17: 15171518.

55. Koutsilieris M, Sourla A, Pelletier G, Doillon CJ. (1994) Three-dimensional type I collagen gel system for the study of osteoblastic metastases produced by metastatic prostate cancer. $J$. Bone Miner. Res. 9: 1823-1832.

56. Sourla A, Doillon C, Koutsilieris M. (1996) Three-dimensional type I collagen gel system containing MG-63 osteoblasts-like cells as a model for studying local bone reaction caused by metastatic cancer cells. Anticancer Res. 16: 2773-2780.

57. Baserga R. (1995) The insulin-like growth factor 1 receptor: a key to tumor growth? Cancer Res. 55: 249-252.

58. Resnicoff M, Abraham D, Yutanawiboonchai $\mathrm{W}$, et al. (1995) The insulin-like growth factor 1 receptor protects tumor cells from apoptosis in vivo. Cancer Res. 55: 2463-2469.

59. Resnicoff M, Burgaud JL, Rotman HL, Abraham D, Baserga R. (1995) Correlation between apoptisis, tumorigenesis, and levels of insulinlike growth factor 1 receptors. Cancer Res. 55: 3739-3741.

60. Sell C, Baserga R, Rubin R. (1995) Insulin-like growth factor 1 (IGF-I) and the IGF-I receptor prevent etoposide-induced apoptosis. Cancer Res. 55: 303-306.

61. Parrizas M, LeRoith D. (1997) Insulin-like growth factor- 1 inhibition of apoptosis is associated with increased expession of the bcl- $\mathrm{X}_{\mathrm{L}}$ gene product. Endocrinology 138: 1355-1358.

62. Parrizas M, Saltiel AR, LeRoith D. (1997) Insulin-like growth factor 1 inhibits apoptosis using the phosphatidylinositol 3'-kinase and mitogen-activated protein kinase pathways. J. Biol. Chem. 272: 154-161.

63. Jelinek DF, Witzig TE, Arendt BK. (1997) A role for insulin-like growth factor in the regulation of IL-6-responsive human myeloma cell line growth. J. Immunol. 159: 487-496.

64. Damiano JS, Cress AE, Hazlehurst LA, Shtil AA, Dalton W. (1999) Cell adhesion mediated drug resistance (CAM-DR): role of integrins and resistance to apoptosis in human myeloma cell lines. Blood 93: 1658-1667.

65. Quigley CA, De Bellis A, Marschke KB, et al. (1995) Androgen receptor defects: historical, clinical, and molecular perspective. Endocr. Rev. 16: 271-321.

66. Van der Kwast TH, Shalken J, de Winter JA, et al. (1991) Androgen receptor in endocrinetherapy-resistant human prostate cancer. Int. J. Cancer 48: 189-193.

67. Lopez-Otin C, Diamandis EP. (1998) Breast and prostate cancer: an analysis of common epidemiological, genetic, and biochemical features. Endocr. Rev. 19: 365-396.

68. Taplin ME, Bubley GJ, Shuster TD, et al. (1995) Mutation of the androgen-receptor gene in metastatic androgen-independent prostate cancer. N. Engl. J. Med. 332: 1393-1398.

69. Dupont A, Gomez JL, Cusan L, Koutsilieris M, Labrie F. (1993) Response to flutamide withdrawal in advanced prostate cancer in progression under combination therapy. J. Urol. 150: 908-913.

70. Veldscholte J, Ris-Stalpers C, Kuiper GJM, et al. (1990) A mutation in the ligand binding domain of the androgen receptor of human LNCaP cells affects steroid binding characteristics and response to anti-androgens. Biochem. Biophys. Res. Commun. 173: 534-540.

71. Suzuki H, Akakura K, Komiya A, Aida S, Akimoto S, shimazaki J. (1996) Codon 877 mutation in the androgen receptor gene in advanced prostate cancer: relation to antiandrogen withdrawal syndrome. Prostate 29: 153-158.

72. Culig Z, Klocker H, Ebere J, et al. DNA sequence of the androgen receptor in prostatic tumor cell lines and tissue specimens assessed by means of the polymerase chain reaction. Prostate 22: 11-22.

73. Visakorpi, T, Hyytinen e, Kovisto $P$, et al. (1995) Amplification of the androgen receptor gene is common in recurrent prostate cancer from patients treated with androgen withdrawal. J. Urol. 153: 379A, [abstract 603].

74. Koivisto P, Kononen J, Palmberg C, et al. (1997) Androgen receptor gene amplification: a possible molecular mechanism for androgen deprivation therapy failure in prostate cancer. Cancer Res. 57: 314-319.

75. Gottlieb B, Lehvaslaiho H, Beitel LK, Lum- 
broso R, Pinsky L, Trifiro M. (1998) The androgen receptor gene mutation database. Nucleic Acids Res. 26: 234-238.

76. Ruijter E, Van de Kaa C, Miller G, Ruiter D, Debruyne F, Schalken J. (1999) Molecular genetics and epidemiology of prostate carcinoma. Endocr. Rev. 20: 22-45.

77. Suzuki H, Sato N, Watabe Y, Masai M, Seino S, Shimazaki J. (1993) Androgen receptor gene mutation in human prostate cancer. J. Steroid Biochem. Mol. Biol. 46: 759-765.

78. Castagnaro M, Yandell DW, DockhornDworhiczak B, Wolfe HJ, Pormeba C. (1993) Human androgen receptor gene mutations and p53 analysis in advanced prostate cancer. Verh. Dtsch. Ges. Pathol. 77: 119-123.

79. Evans BAJ, Harper ME, Daniells CE, et al. (1996) Low incidence of androgen receptor gene mutations in human prostatic tumors using single strand conformation polymorphism analysis. Prostate 28: 162-171.

80. Elo JP, Kvist L, Leinonen K, et al. (1995) Mutated human androgen receptor gene detected in a prostatic cancer patient is also activated by estradiol. J. Clin. Endocrinol. Metab. 80: 3494-3500.

81. Peterziel H, Culig Z, Stober J, et al. (1995) Mutant androgen receptors in prostatic tumors distinguish between amino-acid-sequence requirements for transactivation and ligand binding. Int. J. Cancer 63: 544-550.

82. Taplin ME, Bubley GJ, Shuster TD, et al. (1995) Mutations of the androgen-receptor gene in metastatic androgen-independent prostate cancer. N. Engl. J. Med. 332: 1393-1398.

83. Tilley WD, Buchanan G, Hickey TE, Bentel JM. (1996) Mutations in the androgen receptor gene are associted with progression of human prostate cancer to androgen independence. Clin. Cancer Res. 2: 277-285.

84. Crocitto LE, Henderson BE, Coetzee GA. (1997) Identification of two germline point mutations in the 5'UTR of the androgen receptor gene in men with prostate cancer. J. Urol. 158: 1599-1607.

85. Koivisto P, Kolmer M, Visakorpi T, Kallioniemi OP. (1998) Androgen receptor gene and hormonal therapy failure of prostate cancer. Am. J. Pathol. 152: 1-9.

86. Ottval ZN, Korsemeyer SJ. (1996) Checkpoints of dueling dimers foil death wishes. Cell 79: 189-192.

87. Gajewski TF, Thompson CB. (1996) Apoptosis meets signal transduction: elimination of a BAD influence. Cell 86: 589-592.

88. Zha J, Harada H, Yang E, Jockel J, Korsmeyer SJ. (1996) Serine phosphorylation of death agonist $\mathrm{BAD}$ in response to survival factor results in binding to $14-3-3$ not $\mathrm{Bcl}-\mathrm{X}_{\mathrm{L}}$. Cell 87: 619-628.

89. de La Coste A, Perret C. (1997) Bad est-elle la proteins sible des facteurs de survie? Med. Sci. 3: 384-386.

90. Reed JC. (1998) Bcl-2 family proteins. Oncogene 17: 3225-3236.

91. Ikonen T, Palvimo JJ, Kallio PJ, Reinikainen P, Janne OA. (1994) Stimulation of androgenregulated transactivation by modulation of protein phosphorylation. Endocrinology 135: 1359-1366.

92. Culig Z, Hobisch A, Cronauer MV, et al. (1994) Androgen receptor activation in prostatic tumor cell lines by insulin-like growth factor-1, keratinocyte growth factor, and epidermal growth factor. Cancer Res. 54: 5474-5478.

93. McConkey DJ, Greene G, Pettaway CA. (1996) Apoptosis resistance increases with metastatic potential in cells of human LNCaP prostate carcinoma line. Cancer Res. 56: 5594-5599.

94. Chang HC, Miyamoto H, Marwah P, et al. (1999) Suppression of Delta(5)-androstenediol-induced androgen receptor transactivation by selective steroids in human prostate cancer cells. Proc. Natl. Acad. Sci. U.S.A. 96: 11173-11177

95. Walker-Daniels J, Coffman K, Azimi M, et al. (1999) Overexpression of the EphA2 tyrosine kinase in prostate cancer. Prostate 41: 275-280.

96. Bubendrof L, Kolmer M, Kononen J, et al. (1999) Hormone therapy failure in human prostate cancer: analysis by complementry DNA and tissue microarrays. J. Natl. Cancer Inst. 91: 1758-1764.

97. Koutsilieris M. (1992) PA-III rat prostate adenocarcinoma cells (review). In Vivo 6: 199-203.

98. Dalany AM, Canalis E. (1995) Transcriptional regression of insulin-like growth factor 1 by glucocorticoids in rat bone cells. Endocrinology 136: 4776-4778.

99. Chen TL, Mallory JB, Hintz RL. (1991) Dexamethasone and 1,25(OH)2 vitamin $\mathrm{D} 3$ modulate the synthesis of insulin-like growth factor1 in osteoblast-like cells. Calcif. Tissue Int. 48: 278-282.

100. Koutsilieris M, Reyes-Moreno C, Sourla A, Dimitriadou V, Choki I. (1997) Growth factors mediate glucocorticoid receptor function and dexamethasone-induced regression of osteoblastic lesions in hormone refractory prostate cancer. Anticancer Res. 17: 1461-1465.

101. Treon SP, Anderson KC. (1998) Interleukin-6 in multiple myelome and related plasma cell dyscrasias. Curr. Opin. Hematol. 5: 42-48.

102. Caligaris-Cappio F, Bergui L, Gregoretti MG, et al. (1991) Role of bone marrow stromal cells in the growth of human multiple myeloma. Blood 77: 2688-2693.

103. Bataille R, Chappard D, Marcelli C, et al. (1991) Recruitment of new osteoblasts and osteoclasts is the earliest critical event in the pathogenesis of human multiple myeloma. J. Clin. Invest. 88: 62-66. 
104. Caligaris-Cappio F, Gregoretti MG, Ghia P, Bergui L. (1992) In vitro growth of human multiple myeloma: implication for biology and therapy. Hematol. Oncol. Clin. North Am. 6: 257-271.

105. Manolagas SC. (1998) The Role of IL-6 type cytokines and their receptors in bone. Ann. NY Acad. Sci. 840: 194-204.

106. Swolin-Eide D, Ohlsson C. (1998) Effects of cortisol in the expression of interleukin- 6 and interleukin-1 beta in human osteoblast-like cells. J. Endocrinol. 156: 107-1 14.

107. Hierl T, Borcsok I, Sommer U, Ziegler R, Kasperk C. (1998) Regulation of interleukin-6 expression in human osteoblastic cells in vitro, Exp. Endocrinol. Diabetes 106: 324-333.

108. Borsellino N, Belldegrun A, Bonavida B. (1995) Endogenous interleukin-6 is a resistance factor for cis-diamminedichloroplatinum and etoposide-mediated cytotoxicity of human prostate carcinoma cell lines, Cancer Res. 55: 4633-4639.

109. Drachenberg DE, Elgamal AA, Rowbotham R, Peterson M, Murphy GP. (1999) Circulating levels of interleukin-6 in patients with hormone-refractory prostate cancer. Prostate 41: 127-133.

110. Elomaa I, Taube T, Blomqvist C, Rissanen P, Rannikko S, Alfthan O. (1998) Aminoglutethimide for advanced prostatic cancer resistance to conventional hormonal therapy. Eur. Urol. 14: 104-106.

111. Ponder BA, Shearer RJ, Pocock RD, et al. (1995) Response to aminoglutethimide and cortisone acetate in advanced prostatic cancer. Br. J. Cancer 50: 757-763.

112. Plowman PN, Perry LA, Chard T. (1987) Androgen suppression by hydrocortisone without aminoglutethimide in orchiectomised men with prostatic cancer. Br. J. Urol. 59: 255-257.

113. Manni A, Santen RJ, Boucher AE, et al. (1987) Androgen depletion and repletion as a means of potentiating the effect of cytotoxic chemotherapy in advanced prostate cancer. J. Steroid Biochem. 27: 551-556.

114. Enomoto Y, Fukuhara H, Kurimoto S, et al. (1989) A case of hormone-refractory prostate cancer responsive to low-dose prednisolone therapy. Nippon Hinyokika Gakkai Zasshi 88: 636-639.

115. Kelly WK, Scher HI, Mazumdar M, et. al. Suramin and hydorcortisone: determining drug efficacy in androgen-independent prostate cancer. J. Clin. Oncol. 13: 22 14-2222.

116. Figg WD, Kroog G, Duray P, et al. (1997) Flutamide withdrawal plus hydrocortisone resulted in clinical complete response in a patient with prostate carcinoma. Cancer 79: 1964-1968.

117. Small EJ, Baron A, Bok R. (1997) Simultaneous antiandrogen withdrawal and treatment with ketoconazole and hydrocortisone in patient with advanced prostate carcinoma. Cancer 80: 1755-1759.

118. Labrie F, Dupont A, Belanger A, et al. (1989) Anti-hormone treatment for prostate cancer relapsing after treatment with flutamide and castration. Addition of aminoglutethimide and low dose hydrocortisone to combination therapy. Br. J. Urol. 63: 634-638.

119. Hellmann K, Phillips RH, Gold M. (1993) Highdose dexamethasone and base of brain irradiation for hormone refractory metastatic carcinoma of the prostate. Clin. Exp. Metastasis 11: 227-229.

120. Villafuerte BC, Goldstein S, Robertson DG, Pao CI, Murphy LJ, Phillips LS. (1992) Nutrition and somatomedin XXIX, Molecular regulation of IGFBP-1 in hepatocyte primary culture. Diabetes 41: 835-842.

121. Giustina A, Veldhuis JD. (1999) Pathophysiology of the neuroregulation of growth hormone secretion in the experimental animals and the human. Endocr. Rev. 19: 717-797.

122. Davies $\mathrm{PH}$, Stewart SE, Lancranjan L, et al. (1998) Long-term therapy with long-acting octreotide (Sandostatin-LAR) for the management of acromegaly. Clin. Endocrinol. (Oxf). 48: 311-316. (Published erratum appears in Clin. Endocrinol. (Oxf). 1998, 48: 673).

123. Ezzat S, Ren SG, Braunstein GD, Melmed S. (1992) Octreotide stimulates insulin-like growth factor-binding proteisn-1: a potential pituitary-independent mechanism for drug action. J. Clin. Endocrinol. Metab. 75: 1459-1463.

124. Sinisi AA, Bellastella A, Prezioso D, et al. (1997) Different expression patterns of somatostatin receptor subtypes in cultured epithelial cells from human normal prostate and prostate cancer. J. Clin. Endocrinol. Metab. 82: 2566-2569.

125. Brevini TA, Bianchi R, Motta M. (1993) Direct inhibitory effect of somatostatin on the growth of the human prostatic cancer cell line LNCaP: possible mechanism of action. J. Clin. Endocrinol. Metab. 77: 626-631.

126. Koppan M, Nagy A, Schally AV, Arencibia JM, Polonowski A, Halmos G. (1998) Targeted cytotoxic analogue of somatostatin AN-238 inhibits growth of androgen-independent Dunning R-3327-AT- 1 prostate cancer in rats at nontoxic doses. Cancer Res. 58: 4132-4137.

127. Nagy A, Schally AV, Halmos G, et al. (1998) synthesis and biological evaluation of cytotoxic of analogs of somatostatin containing doxorubicin or its intensely potent derivative, 2-pyrrolinodoxorubicin. Proc. Natl. Acad. Sci. U.S.A. 95: 1794-1799.

128. Figg WD, Thibault A, Cooper MR, et al. (1995) A phase I study of the somatostatin analogue somatuline in patients with metastatic hormone-refractory prostate cancer. Cancer 75: 2159-2164. 
129. Maulard C, Richaud P, Droz JP, et al. (1995) Phase I-II study of the somatostatin analogue lanreotide in hormone-refactory prostate cancer. Cancer Chemother. Pharmacol. 36: 259-262.

130. Vainas G, Pasaitou V, Galaktidou G, et al. (1997) The role of somatostatin analogues in complete antiandrogen treatment in patients with prostatic carcinoma. J. Exp. Clin. Cancer Res. 16: 119-126.

131. Koutsilieris M, Tzanela M, Dimopoulos T. (1999) The novel concept of anti-survival factor (ASF) therapy produces an objectives clinical response in four patients with hormone refractory prostate cancer: case report. Prostate 38: 313-316.

132. Treon SP, Anderson KC. (1998) Interleukin-6 in multiple myeloma and related plasma cell dyscrasias. Curr. Opin. Hematol. 5: 42-48.

133. Anderson KC, Jones RC, Morimoto C, Leavitt P, Barut B. (1989) Response of purified myeloma cells to hematopoietic growth factors. Blood 73: 1915-1924.

134. Urashima M, Ogata A, Chauhan D, et al. (1996) Interleukin-6 promotes multiple myeloma cell growth via phosphorylation of retinoblastoma protien. Blood 88: 2219-2227.

135. Urashima $M$, Chauhan D, Uchiyama H, Freeman GJ, Anderson HC. (1995) CD40 ligand triggered interleukin- 6 secretion in multiple myeloma. Blood 85: 1903-1912.

136. Chauhan D, Uchiyama H, Akbarali Y, et al. (1996) Multiple myeloma cell adhesioninduced interleukin- 6 expression in bone marrow stromal cells involves activation of NF $\kappa$ B. Blood 87: 1104-1112.

137. Lichtenstein A, Tu Y, Fady C, Vescio R, Berenson J. (1965) Interleukin-6 inhibits apoptosis of malignant plasma cells. Cell Immunol. 162: 284-245.

138. Kawano MM, Mihara K, Huang N, Tsujimoto T, Kuramato A. (1995) Differentiation of early plasma cells on bone marrow stormal requires interleukin-6 for escaping from apoptosis. Blood 85: 487-494.

139. Hata H, Matsuzaki H, Takeya M, et al. (1995) Expression of Fas/Apo-1 (CD-95) and apoptosis in tumor cells from patients with plasma cells disorders. Blood 86: 1939-1945.
140. Catlett-Falcone R, Landowski TH, Oshiro MM, et al. (1999) Constitutive activation of Stat3 signaling confers resistance to apoptosis in human U266 myeloma cells. Immunity 10: 105-115.

141. Xu F, GardnerA, Tu Y, Michi P, Prager D, Lichtenstein A. (1997) Multiple myeloma cells are protected against dexamethasone-induced apoptosis by insulin-like growth factor. Br. J. Haematol. 97: 429-440.

142. Georgii-Hemming $\mathrm{P}$, Wiklund HJ, Ljunggren O, Nilsson K, (1996) Insulin-like growth factor $l$ is a growth and survival factor in human multiple myeloma cell lines. Blood 88: 22502258.

143. Kawamoto K, Onodera H, Kan S, Kondo S, Imamura M. (1999) Possible paracrine mechanism carcinoma of insulin-like growth factor-2 in the development of liver metastases from colorectal carcinoma. Cancer 85: 18-25.

144. Long L, Nip J, Brodt P. (1994) Paracrine growth stimulation by hepatocyte-derived insulin-like growth factor-1: a regulatory mechanism for carcinoma cells metastatic to the liver. Cancer Res. 54: 3732-3737.

145. Long L, Rubbin R, Baserga R, Brodt p. (1995) Loss of the metastatic phenotype in murine carcinoma cells expressing an antisense RNA to the insuline-like growth factor receptor. Cancer Res. 55: 1006-1009.

146. Long L, Rubin R, Brodt P. (1998) Enhanced invasion and liver colonization by lung carcinoma cells overexpressing the type 1 insulinlike growth factor receptor. Exp. Cell Res. 238: 116-121.

147. Huynh HT, Tetenes E, Wallace L, Pollak M. (1993) In vivo inhibition of insulin-like growth factor 1 gene expression by tamoxifen, Cancer Res. 53: 1727-1730.

148. Yee D, Morales FR, Hamilton TC, Von Hoff DD. (1991) Expression of insulin-like growth factor 1 , its binding proteins, and its receptor in ovarian cancer. Cancer Res. 51: 5107-5112.

149. Beck EP, Russo P, Gliozzo B, et al. (1994) Identification of insulin and insulin-like growth factor 1 (IGF I) receptors in ovarian cancer tissue. Gynecol. Oncol. 53: 196-201. 